\title{
Effects of Volatile Anesthetics on Proliferation and Viability of SW480 Colon Cancer Cells In Vitro
}

\author{
ANIKA C. BUNDSCHERER ${ }^{1 *}$, VIKTORIA ULLRICH ${ }^{1,2^{*}}$, MANUELA MALSY $^{1}$, MICHAEL A. GRUBER $^{1}$, \\ BERNHARD M. GRAF ${ }^{1}$, GERO BROCKHOFF $^{3}$ and BARBARA SINNER ${ }^{1}$ \\ ${ }^{1}$ Department of Anesthesiology, University Hospital of Regensburg, Regensburg, Germany; \\ ${ }^{2}$ Department of Pediatrics, Barmherzigen Brueder Hospital, Regensburg, Germany; \\ ${ }^{3}$ Department of Gynecology, University Medical Center, University of Regensburg, Regensburg, Germany
}

\begin{abstract}
Background/Aim: For patients undergoing cancer surgery, the risk for cancer progression is enhanced during the perioperative period. To what extent the type of anesthetic can affect the metastatic process and finally the outcome of patients with cancer is under debate. For this reason, the aim of this study was to investigate the effects of the volatile anesthetics sevoflurane and desflurane on colon cancer cells in vitro. Materials and Methods: SW480 colon carcinoma cells were exposed for 3 or $6 \mathrm{~h}$ to sevoflurane ( 1 or 2.5 vol\%) or desflurane (6 or 12 vol\%). Cell cycle distribution was analyzed by flow cytometry after a 24-72 $h$ recovery and apoptosis was detected by annexin $V$ staining after a 0-48 h recovery. Viability was tested by measuring ATP content after 0 and $24 \mathrm{~h}$ recovery. Results: Treatment with sevoflurane or desflurane caused no or only slight changes in cell-cycle distribution and apoptosis rate. Desflurane at $12 \mathrm{vol} \%$ significantly reduced cell viability by $17 \pm 25 \%$ and $11 \pm 22 \%$ after 3 and $6 h$ incubation and $24 \mathrm{~h}$ recovery, respectively, while 2.5 vol\% sevoflurane slightly increased viability. Conclusion: At clinically relevant concentrations, sevoflurane and desflurane had only slight effects on SW480 colon cancer cells in vitro.
\end{abstract}

This article is freely accessible online.

*These Authors equally contributed to this study.

Presented at: DAC (German Congress of Anesthesiology) 2017 Nürnberg.

This study is part of the thesis of Viktoria Ullrich.

Correspondence to: Anika Bundscherer, Department of Anesthesiology, University of Regensburg, Franz Josef Strauß Allee 11, 93053 Regensburg, Germany. Tel: +49 9419447801, Fax: +49 9419447802, e-mail: anika.bundscherer@ukr.de

Key Words: Colon cancer, volatile anesthetics, sevoflurane, desflurane, cell cycle, apoptosis.
For patients undergoing cancer surgery, the risk for cancer dissemination and metastasis is supposed to be enhanced during the perioperative period $(1,2)$. Cancer cells are released into the circulation due to traumatization of tumor vessels and surgical manipulation of the tumor tissue (3). Increased levels of growth factors and an imbalance between pro- and antiangiogenic factors can be detected during the wound-healing process (4). At the same time, impairment of the immune response occurs for several days after cancer surgery (1).

Anesthesia as well as surgical trauma activates the neuroendocrine stress response by stimulating the hypothalamic-pituitary-adrenal axis and the sympathetic nervous system, leading to increased levels of immunosuppressive factors such as catecholamines, glucocorticoids and prostaglandins (5). With reduced numbers of natural killer cells, cytotoxic T-cells and T-helper cells, cell-mediated immunity is attenuated (6). For this reason, the growth of disseminated cancer cells and micrometastases can be fostered during the perioperative period.

Usually anesthesia is induced by the administration of intravenous anesthetics and maintained either by volatile anesthetics or as total intravenous anesthesia. Balanced anesthesia that combines several agents to achieve unconsciousness, amnesia, analgesia and muscle relaxation, and minimization of adverse effects by reducing the dosage of the single agents is a well-established anesthesia regime (7). In terms of a multimodal pain therapy management, opioid analgesics are often combined with other agents such as ketamine and non-opioide-analgesics (8). If applicable, regional anesthetic techniques such as epidural anesthesia, paravertebral blockade or blockade of peripheral nerves are applied to improve intra- and postoperative pain management (8).

It remains unknown whether the application of a special anesthesia regime or agents can affect cancer recurrence and oncological outcome. A large number of preclinical and clinical studies are currently addressing this issue. The aim of this study was to investigate the effects of the volatile anesthetics 
sevoflurane and desflurane on viability, apoptosis and cellcycle distribution of SW480 colon cancer cells in vitro.

\section{Materials and Methods}

Reagents. Commercially available sevoflurane (Sevorane ${ }^{\circledR}$; Abbvie, Ludwigshafen, Germany) and desflurane (Suprane ${ }^{\circledR}$; Baxter, Unterschleißheim, Germany) were used for this study.

Cell line. SW480 colon carcinoma cell line was purchased from the German Collection of Microorganism and Cell Culture (DSMZ, Braunschweig, Germany). RPMI 1640 medium (Pan Biotech, Aidenbach, Germany) contained $10 \%$ fetal calf serum (SigmaAldrich, Steinheim, Germany), $2 \mathrm{mM}$ sodium pyruvate (Appli Chem, Darmstadt, Germany) and $2 \mathrm{mM}$ L-glutamine (Sigma-Aldrich) and was supplemented with 5\% penicillin plus streptomycin (SigmaAldrich). Cells were maintained in monolayer culture and were cultured in a humidified $\mathrm{CO}_{2}$ atmosphere $(5 \%)$ at $37^{\circ} \mathrm{C}$. Experiments were performed when cells reached $\sim 80 \%$ confluence.

Exposure to volatile anesthetics. SW480 $\left(2.5-3 \times 10^{5}\right)$ cells were seeded in $25-\mathrm{cm}^{2}$ cell culture flasks (BD Falcon, Heidelberg, Germany) and allowed to attach for 2-3 days.

Cells were exposed to sevoflurane (1 or 2.5 vol\%) or desflurane ( 6 or $12 \mathrm{vol} \%$ ) for a period of 3 or $6 \mathrm{~h}$. A modified anesthesia unit (Trajan 808; Draeger, Lübeck, Germany) was used as described previously (9). Anesthesia gas vaporizers were installed for the evaporation of sevoflurane (Vapor Sevorane ${ }^{\circledR}$; ABBOTT Draeger, Lübeck, Germany) or desflurane (Vapor Devapor; Draeger). The gas mixture $\left(95 \%\right.$ air and $5 \% \mathrm{CO}_{2}$ plus 1 or 2.5 vol\% sevoflurane or 6 or 12 vol\% desflurane) was continuously monitored using a Capnomak Ultima monitor (Datex Engstrom, Fairfield, CT, USA). In addition, sevoflurane and desflurane concentration dissolved in culture medium was detected by gas chromatography. Cells were maintained at $37^{\circ} \mathrm{C}$ by placing the cell-culture flasks on feedbackregulated heated gel pads. To prevent protein binding of volatile anesthetics, standard growth medium was replaced by serum-free medium in all groups (including controls) during anesthetic exposure. After exposure, cells were washed once and incubated with standard growth medium and cells were returned into the incubator for recovery.

Cell-cycle analysis. Cell-cycle profiles were analyzed by flow cytometry after treatment with sevoflurane (1 or 2.5 vol\%) or desflurane (6 or 12 vol\%) and a 24- to 72-h recovery. Standard culture medium was used for negative control and $5 \mathrm{mM}$ acetylsalicylic acid (ASS) (Sigma-Aldrich) was used for positive control. Cells were harvested by standard trypsinization and washed twice with cold phosphate-buffered saline (PBS)/1\% fetal calf serum. Cells $\left(2.5 \times 10^{5}\right)$ were fixed with $70 \%$ methanol at room temperature and stored at $4{ }^{\circ} \mathrm{C}$. For measuring, the cells were washed twice with PBS and treated with $1 \mathrm{mg} / \mathrm{ml}$ RNase A. After a 20-min incubation at room temperature in the dark, cells were stained with $100 \mu \mathrm{g} / \mathrm{ml}$ propidium iodide (PI) (Sigma-Aldrich). For each sample, $10^{4}$ cells were measured by flow cytometry using FACS Calibur (BD Bioscience, Franklin Lakes, NJ, USA) driven by the CellQuest Software (BD Bioscience). The cellcycle distribution was assessed using ModFit LT 3.2 software (Verity Software House, Topsham, ME, USA). All tests were performed as at least three independent experiments.
Apoptosis analysis. Apoptosis rate was measured after treatment with sevoflurane (1 or 2.5 vol\%) or desflurane (6 or $12 \mathrm{vol} \%$ ) and $0-48 \mathrm{~h}$ recovery. Staurosporine $(1 \mu \mathrm{M}$; Sigma Aldrich) was used as a positive control. Floating cells were preserved by decanting supernatant. Adherent cells were rinsed with PBS $\left(37^{\circ} \mathrm{C}\right)$ (SigmaAldrich) and detached by standard trypsinization. Fluorescein isothiocyanate Annexin V Apoptosis detection Kit (BD, Heidelberg, Germany) was used according to the manufacturer's protocol as described previously, PI staining was used for the exclusion of necrotic cells (10). All tests were performed in duplicates as at least three independent experiments. For data analysis, Flowjo v10.0.7 (BD, Ashland, OR, USA) was used.

Cell viability. Cell viability was measured by the Glo Lumninescent assay (Cell Titer Glo Luminescence) (Promega, Madison, WI, USA) according the manufacturer's protocol. SW480 colon cancer cells $\left(4 \times 10^{4}\right)$ were seeded in six 24-well plates and allowed to attach for 23 days. Standard growth medium was replaced by serum-free medium and plates were incubated for 0,3 or $6 \mathrm{~h}$ with 2.5 vol\% sevoflurane or $12 \mathrm{vol} \%$ desflurane. Three wells were used for each control, $3 \mathrm{~h}$ and $6 \mathrm{~h}$ incubation time and 0 and $24 \mathrm{~h}$ recovery time (separate plates). Cell viability was analyzed directly after incubation and after $24 \mathrm{~h}$ recovery time. Cell Titer Glo reagent $(285 \mu \mathrm{l})$ was added to each experimental well of the 24 -well plate containing $285 \mu \mathrm{L}$ culture medium and contents were mixed for 2 min to induce cell lysis. The content was transferred to 5 wells of a 96-well plate with $100 \mu$ per well and allowed to incubate at room temperature for $15 \mathrm{~min}$. Luminescence signal was detected by a Varioskan Flash (Thermo Fisher Scientific, Waltham, MA, USA) multiplate reader using Skanit 2.4.5 software (Thermo Fisher Scientific). For data analysis, an ATP (Sigma) standard curve was generated. All experiments were performed in triplicates as three independent experiments.

Statistical analysis. Results are expressed as the mean \pm standard deviation (SD). For comparison between mean values, the nonparametric Mann-Whitney $U$-test was used. Differences were considered statistically significant at $p<0.05$. IBM SPSS Statistics V 21 (IBM, New York, NY, USA) and Excel 2010 (Microsoft, Redmond, Washington, USA) packages were employed for statistical analysis.

\section{Results}

Cell-cycle analysis. After exposure to sevoflurane or desflurane, only slight changes in the cell-cycle distribution were detected. In SW480 cells exposed to 1 vol\% sevoflurane for 3-h and 24-h recovery, the fraction of cells in $G_{2}$ phase significantly decreased from $10.6 \pm 1.3 \%$ to $9.4 \pm 0.8 \%$ compared to the untreated control $(p<0.05)$ (Figure 1A). After $6 \mathrm{~h}$ of exposure to $2.5 \mathrm{vol} \%$ sevoflurane, a significant increase in $\mathrm{G}_{2}$ phase cells was detected compared to the untreated control from $5.8 \pm 0.5 \%$ to $8.6 \pm 1.7 \%$ after $48 \mathrm{~h}$ and from $6.1 \pm 0.8 \%$ to $7.6 \pm 0.6 \%$ after $72 \mathrm{~h}$ recovery $(p<0.01)$ (Figure 1B). In cells treated with $6 \mathrm{vol} \%$ desflurane for $6 \mathrm{~h}$ or $12 \mathrm{vol} \%$ for $3 \mathrm{~h}$, an increase in S-phase cells from $27.4 \pm 1.3 \%$ to $30.2 \pm 1.8 \%$ and $28.5 \pm 0.9 \%$ to $30.7 \pm 0.9 \%$ respectively, compared to the corresponding control cells, was detected after a 48-h recovery $(p<0.01)$ (Figure $1 \mathrm{C}$ and D). 


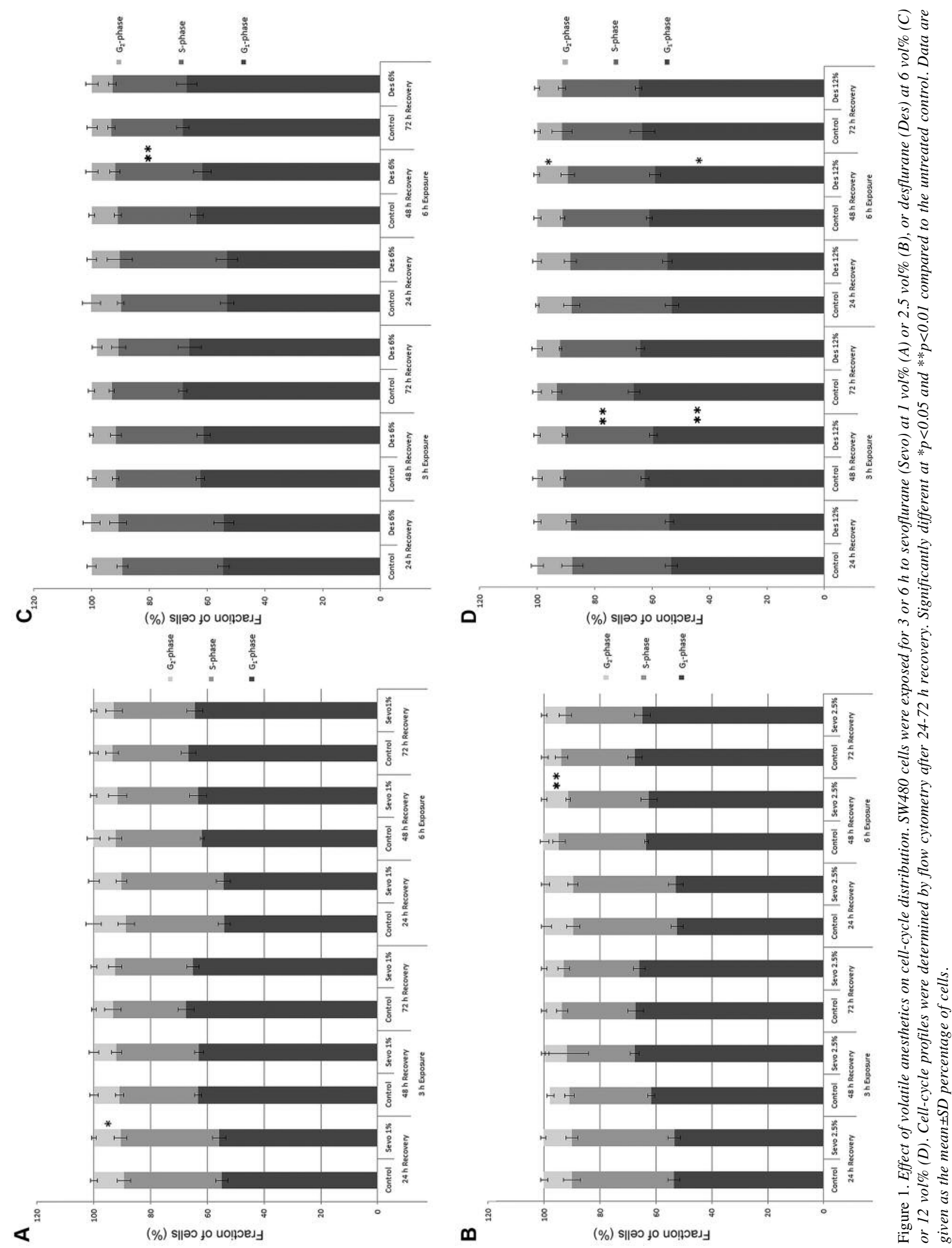




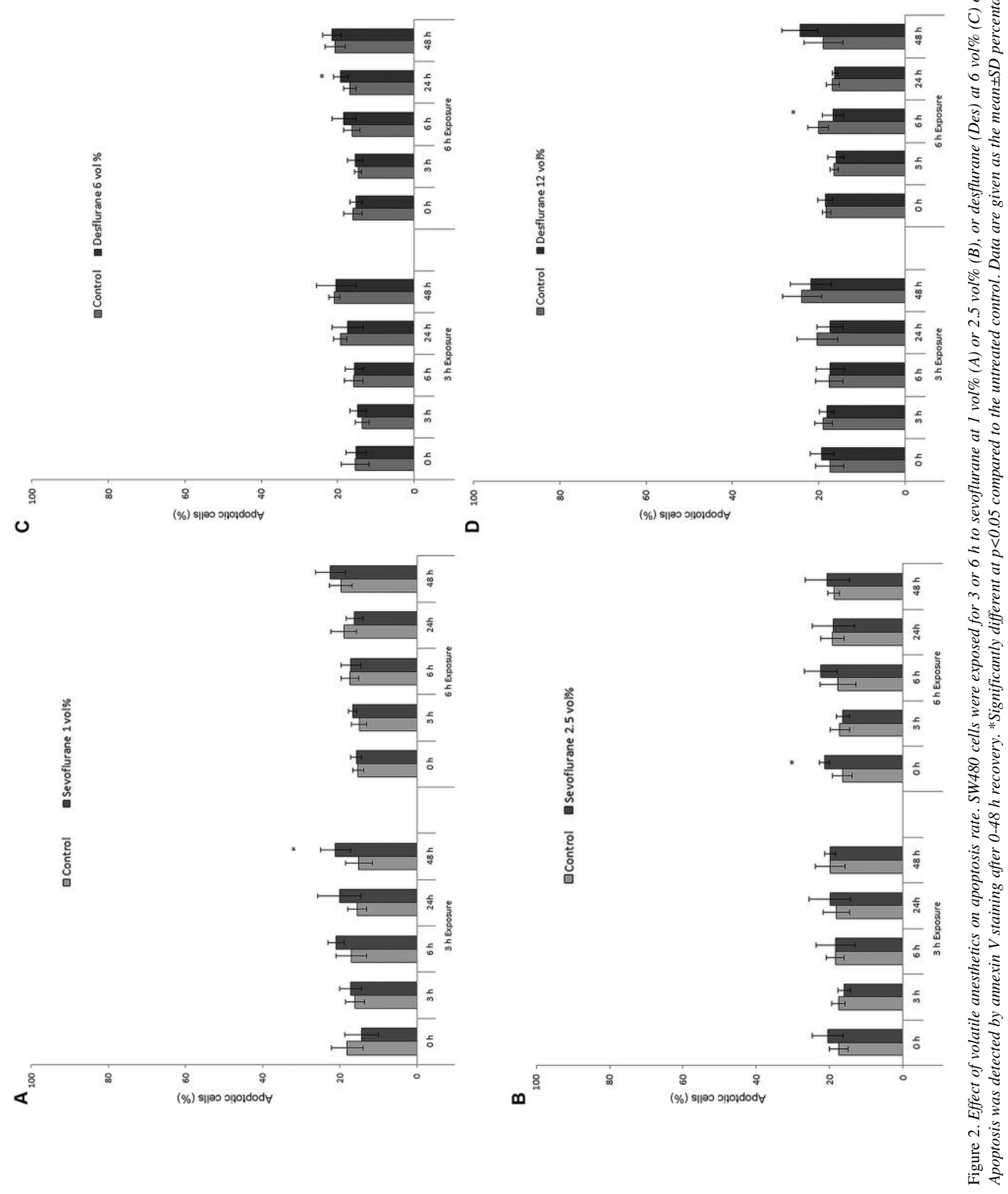


A significant decrease in $\mathrm{G}_{1}$-phase cells occurred in cells exposed to $12 \%$ desflurane for 3 or $6 \mathrm{~h}$ followed by a 48 -h recovery time from $62.5 \pm 1.3 \%$ to $59.6 \pm 1.4 \%$ and $61.1 \pm 1.0 \%$ to $59.0 \pm$ to $1.9 \%$ respectively $(p<0.05)$ (Figure $1 \mathrm{D})$.

Apoptosis analysis. Compared to the untreated control, a statistically significant increase in apoptosis $(15.0 \pm 3.6 \%$ to $21.1 \pm 3.9 \%, p<0.05)$ was detected after a 3 -h exposure to sevoflurane (1 vol\%) and a $48 \mathrm{~h}$ recovery (Figure $2 \mathrm{~A})$, as well as immediately after incubation with 2.5 vol\% sevoflurane for $6 \mathrm{~h}(16.5 \pm 2.7 \%$ to $21.4 \pm 1.3 \%)$ (Figure 2B).

For cells incubated with desflurane 6 vol\% for $6 \mathrm{~h}$, the apoptosis rate increased significantly from $14.1 \pm 1.4 \%$ to $16.4 \pm 1.9 \%$ after $24 \mathrm{~h}$ recovery (Figure $2 \mathrm{C}$ ). However, a significant reduction of apoptotic cells was detected after 6 $\mathrm{h}$ of exposure to $12 \mathrm{vol} \%$ desflurane and a 6-h recovery, from $20.1 \pm 2.5 \%$ to $16.6 \pm 2.5 \%(p<0.05)$ (Figure $2 \mathrm{D})$. No significant changes in apoptosis rate were detected after exposure to sevoflurane or desflurane at any other timepoints.

Cell viability. Incubation with $2.5 \mathrm{vol} \%$ sevoflurane for $3 \mathrm{~h}$ increased cell viability by $8 \pm 17 \%$ and $4 \pm 13 \%$ respectively (Figure 3A). However, after 6-h incubation, no significant changes in ATP content were detected. Incubation with $12 \%$ desflurane for 3 and $6 \mathrm{~h}$ significantly reduced viability after a 24 -h recovery by $17 \pm 25 \%$ and $11 \pm 22 \%$, respectively (Figure 3B).

\section{Discussion}

Sevoflurane and desflurane are volatile anesthetics usually used for balanced anesthesia (7). A common tool to describe the anesthetic potency of volatile anesthetics is the minimal alveolar concentration (MAC) which is required to avoid movement to a surgical stimulation in $50 \%$ of patients, referred to as MAC 50\% (11). For desflurane, MAC 50\% is $6 \mathrm{vol} \%$ and for sevoflurane $2.05 \mathrm{vol} \%$ in oxygen (12). MAC decreases with increasing age and in combination with other depressive agents such as opioids and benzodiazepines (11)

The mechanism of action of volatile anesthetics has not been fully elucidated. For a long time, interaction with the lipid of the cell membrane was purported to be the mechanism of action (12). Later, the involvement of proteins was discussed and, in recent years, binding sites for anesthetics have been detected in different ion channels such as nicotinic acetylcholine, glycine, $N$-methyl-D-aspartate (NMDA), $\alpha$ amino-3-hydroxy-5-methyl-4-isoxazolepropionic acid (AMPA) and serotonin receptors (12).

In this study, we only detected no or slight effects on cell proliferation and viability of SW480 cells upon incubation with sevoflurane and desflurane for 3 or $6 \mathrm{~h}$. These changes were quite small sporadic differences between the groups which did

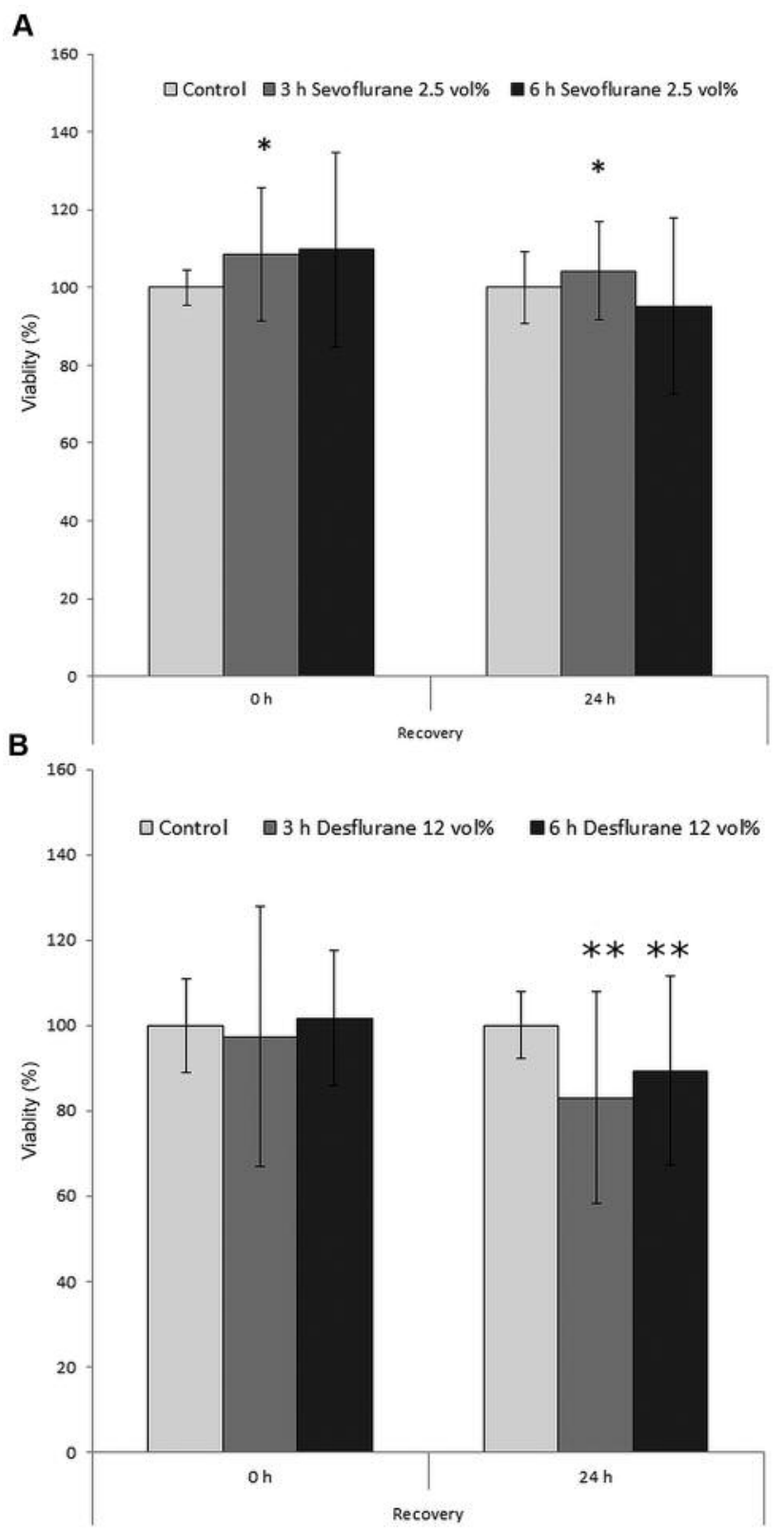

Figure 3. Effect of volatile anesthetics on cell viability. SW480 cells were exposed for 3 or $6 \mathrm{~h}$ to 2.5 vol\% sevoflurane (A), 12 vol\% desflurane (B). Cell viability was detected by ATP assay a 0 or $24 \mathrm{~h}$ recovery time. Significantly different at $* p<0.05$ and $* * p<0.01$ compared to the untreated control. Data are given as the mean $\pm S D$ percentage of cells.

not follow any pattern. For this reason, we do not judge these changes to be a specific effect of sevoflurane or desflurane.

In SW620 and HCT116 colon carcinoma cells, incubation with 1-4\% sevoflurane for $6 \mathrm{~h}$ caused little change in cell viability measured by MTT test. However, inhibition of cell invasion and migration was detected (13). 
Results from several studies show inconsistent effects of volatile anesthetics on cell proliferation, apoptosis and metastatic potential. In A549 lung cancer cells, incubation with sevoflurane enhanced apoptosis, increased apoptotic bodies, impaired DNA integrity (14) and caused changes in apoptosis-related miRNAs (15). Liang and colleagues showed apoptosis induction and inhibition of cell proliferation, as well as anti-invasive and anti-migratory effects by sevoflurane via down-regulation of expression of matrix metalloproteinase (MMP)-2 and -9 (16). Furthermore, co-treatment with sevoflurane and the chemotherapeutic agent cisplatin caused synergistic growth inhibitory and anti-invasive effects (17). However, in another study, the incubation of A549 cells with $3.6 \mathrm{vol} \%$ sevoflurane for $2 \mathrm{~h}$ reduced cell proliferation and increased chemosensitivity but did not affect migration (18). Interestingly, in the same study, the viability and metastatic potential, as well as the chemoresistance, of renal cell carcinoma cells was enhanced (18). Kvolik et al. showed increased apoptosis induced by sevoflurane in Caco 2 colon cancer cells but only moderate effects in laryngeal cancer cells (19). Moreover in head and neck squamous cell carcinoma, sevoflurane inhibited cell invasion and induced apoptosis (20). In contrast, isoflurane was shown to increase proliferation, reduce apoptosis and promote invasion in two head and neck squamous cell carcinoma cell lines (21). In addition, exposure to isoflurane, desflurane or sevoflurane for $2 \mathrm{~h}$ significantly increased the metastatic potency of SKOV-3 ovarian cancer cells by increasing levels of vascular endothelial growth factor A, MMP11 and transforming growth factor beta (22). Isoflurane furthermore caused cell-cycle progression and increased cell growth in ovarian (23) and prostate cancer (24) cells, and attenuated dynorphin-induced cytotoxicity in neuroblastoma cells (25).

In preclinical studies, incubation time ranged from $30 \mathrm{~min}$ (15) to $48 \mathrm{~h}$ (26); in many studies incubation times from 2 to $6 \mathrm{~h}$ were used $(14,20,23,24,27)$. Concentrations used ranged from $1.7 \mathrm{vol} \%$ (16) to $6 \mathrm{vol} \%$ for sevoflurane (26) and from $6.6 \mathrm{vol} \%$ (28) to $12 \mathrm{vol} \%$ for desflurane (26). In this study, SW480 cells were exposed to sevoflurane or desflurane for 3 or $6 \mathrm{~h}$. These incubation times are in accordance with clinical exposure to volatile anesthetics for cancer surgery.

\section{Conclusion}

Sevoflurane and desflurane are common inhalative anesthetics used for the maintenance of anesthesia during many surgical procedures, including cancer surgery. In this study, sevoflurane and desflurane revealed no or only slight effects on cell-cycle distribution and apoptosis of SW480 colon cancer cells. Due to the contradicting results of preclinical studies investigating the effect of volatile anesthetics on cancer cells, a recommendation for clinical praxis cannot yet be given.

\section{Conflicts of Interest}

The Authors declare they have no conflicts of interest in regard to this study.

\section{Authors' Contributions}

$\mathrm{AB}, \mathrm{MM}, \mathrm{MG}$ and $\mathrm{BS}$ designed the study. BS and BG supervised the study. AB, VU, MM and MG performed the assays. AB, VU and $\mathrm{GB}$ analyzed the experimental data. $\mathrm{AB}$ and $\mathrm{VU}$ wrote the article. All Authors revised the article.

\section{Acknowledgements}

The Authors thank Sigrid Bamberger, Regina Lindner, Marion Schindler, Ruth Spaeth and Gerhard Piendl for excellent technical support.

\section{References}

1 Gottschalk A, Sharma S, Ford J, Durieux ME and Tiouririne M: Review article: the role of the perioperative period in recurrence after cancer surgery. Anesth Analg 110: 1636-1643, 2010. PMID: 20435944. DOI: 10.1213/ANE.0b013e3181de0ab6

2 Kirkegaard T, Gogenur $M$ and Gogenur I: Assessment of perioperative stress in colorectal cancer by use of in vitro cell models: A systematic review. PeerJ 5: e4033, 2017. PMID 29158975. DOI: $10.7717 /$ peerj.4033 5695245

3 Tohme S, Simmons RL and Tsung A: Surgery for Cancer: A Trigger for Metastases. Cancer Res 77: 1548-1552, 2017. PMID: 28330928. DOI: 10.1158/0008-5472.CAN-16-1536 5380551

4 Ben-Eliyahu S: The promotion of tumor metastasis by surgery and stress: immunological basis and implications for psychoneuroimmunology. Brain Behav Immun 17(Suppl 1): S27-36, 2003. PMID: 12615183.

5 Kim R: Anesthetic technique and cancer recurrence in oncologic surgery: unraveling the puzzle. Cancer Metastasis Rev 36: 159177, 2017. PMID: 27866303. DOI: 10.1007/s10555-016-9647-8

6 Snyder GL and Greenberg S: Effect of anaesthetic technique and other perioperative factors on cancer recurrence. $\mathrm{Br} \mathrm{J}$ Anaesth 105: 106-115, 2010. PMID: 20627881. DOI: 10.1093/bja/aeq164

7 Tonner PH: Balanced anaesthesia today. Best Pract Res Clin Anaesthesiol 19: 475-484, 2005. PMID: 16013695.

8 American Society of Anesthesiologists Task Force on Acute Pain Management: Practice guidelines for acute pain management in the perioperative setting: an updated report by the American Society of Anesthesiologists Task Force on Acute Pain Management. Anesthesiology 116: 248-273, 2012. DOI: 10.1097/ALN.0b013e31823c1030

9 Dittmar MS, Petermichl W, Lindner R, Sinner B, Graf BM, Schlachetzki $\mathrm{F}$ and Gruber M: In vitro induction of endothelial apoptosis of the post-hypoxic blood-brain barrier by isoflurane but not by sevoflurane and midazolam. PLoS One 10: e0130408, 2015. PMID: 26091107. DOI: 10.1371/journal.pone.0130408 4475016

10 Bundscherer AC, Malsy M, Gruber MA, Graf BM and Sinner B: Acetaminophen and metamizole induce apoptosis in HT29 and SW480 colon carcinoma cell lines in vitro. Anticancer Res 38 : 745-751, 2018. PMID: 29374698. DOI: 10.21873/anticanres. 12280 
11 Eger EI, 2nd: Age, minimum alveolar anesthetic concentration and minimum alveolar anesthetic concentration-awake. Anesth Analg 93: 947-953, 2001. PMID: 11574362

12 Torri G: Inhalation anesthetics: A review. Minerva Anestesiol 76: 215-228, 2010. PMID: 20203550

13 Fan L, Wu Y, Wang J, He J and Han X: Sevoflurane inhibits the migration and invasion of colorectal cancer cells through regulating ERK/MMP-9 pathway by up-regulating $m i R-203$. Eur J Pharmacol 850: 43-52, 2019. PMID: 30685432. DOI: 10.1016/j.ejphar.2019.01.025

14 Wei GH, Zhang J, Liao DQ, Li Z, Yang J, Luo NF and Gu Y: The common anesthetic, sevoflurane, induces apoptosis in A549 lung alveolar epithelial cells. Mol Med Rep 9: 197-203, 2014. PMID: 24248633. DOI: 10.3892/mmr.2013.1806

15 Wang L, Wang T, Gu JQ and Su HB: Volatile anesthetic sevoflurane suppresses lung cancer cells and miRNA interference in lung cancer cells. Onco Targets Ther 11: 56895693, 2018. PMID: 30254461. DOI: 10.2147/OTT.S171672 6140755

16 Liang H, Gu M, Yang C, Wang H, Wen X and Zhou Q: Sevoflurane inhibits invasion and migration of lung cancer cells by inactivating the p38 MAPK signaling pathway. J Anesth 26: 381-392, 2012. PMID: 22349744. DOI: 10.1007/s00540-011$1317-\mathrm{y}$

17 Liang H, Wang HB, Liu HZ, Wen XJ, Zhou QL and Yang CX: The effects of combined treatment with sevoflurane and cisplatin on growth and invasion of human adenocarcinoma cell line A549. Biomed Pharmacother 67: 503-509, 2013. PMID: 23639227. DOI: 10.1016/j.biopha.2013.03.005

18 Ciechanowicz S, Zhao H, Chen Q, Cui J, Mi E, Mi E, Lian Q and Ma D: Differential effects of sevoflurane on the metastatic potential and chemosensitivity of non-small-cell lung adenocarcinoma and renal cell carcinoma in vitro. Br J Anaesth 120: 368-375, 2018. PMID: 29406185. DOI: 10.1016/j.bja. 2017.11.066

19 Kvolik S, Dobrosevic B, Marczi S, Prlic L and Glavas-Obrovac L: Different apoptosis ratios and gene expressions in two human cell lines after sevoflurane anaesthesia. Acta Anaesthesiol Scand 53: 1192-1199, 2009. PMID: 19572936. DOI: 10.1111/j.13996576.2009.02036.x

20 Yang Y, Hu R, Yan J, Chen Z, Lu Y, Jiang J and Jiang H: Sevoflurane inhibits the malignant potential of head and neck squamous cell carcinoma via activating the hypoxia-inducible factor-1alpha signaling pathway in vitro. Int J Mol Med 41: 995 1002, 2018. PMID: 29207062. DOI: 10.3892/ijmm.2017.3306
21 Jun R, Gui-he Z, Xing-xing S, Hui Z and Li-xian X: Isoflurane enhances malignancy of head and neck squamous cell carcinoma cell lines: A preliminary study in vitro. Oral Oncol 47: 329-333, 2011. PMID: 21441066. DOI: 10.1016/j.oraloncology.2011.03.002

22 Iwasaki M, Zhao H, Jaffer T, Unwith S, Benzonana L, Lian Q, Sakamoto A and Ma D: Volatile anaesthetics enhance the metastasis related cellular signalling including CXCR2 of ovarian cancer cells. Oncotarget 7: 26042-26056, 2016. PMID: 27028996. DOI: 10.18632 /oncotarget.8304 5041963

23 Luo X, Zhao H, Hennah L, Ning J, Liu J, Tu H and Ma D: Impact of isoflurane on malignant capability of ovarian cancer in vitro. Br J Anaesth 114: 831-839, 2015. PMID: 25501719. DOI: $10.1093 /$ bja/aeu408

24 Huang H, Benzonana LL, Zhao H, Watts HR, Perry NJ, Bevan $\mathrm{C}$, Brown $\mathrm{R}$ and Ma D: Prostate cancer cell malignancy via modulation of HIF-1alpha pathway with isoflurane and propofol alone and in combination. Br J Cancer 111: 1338-1349, 2014. PMID: 25072260. DOI: 10.1038/bjc.2014.426 4183852

25 Wu GJ, Chen WF, Sung CS, Jean YH, Hung CH, Chen FA, Hsieh $\mathrm{MH}$ and Wen $\mathrm{ZH}$ : Isoflurane attenuates dynorphininduced cytotoxicity and down-regulation of BCL-2 expression in differentiated neuroblastoma SH-SY5Y cells. Acta Anaesthesiol Scand 53: 55-60, 2009. PMID: 19032555. DOI: 10.1111/j.1399-6576.2008.01828.x

26 Lin D, Feng C, Cao M and Zuo Z: Volatile anesthetics may not induce significant toxicity to human neuron-like cells. Anesth Analg 112: 1194-1198, 2011. PMID: 20966438. DOI: 10.1213/ANE.0b013e3181fdf69d

27 Yi W, Li D, Guo Y, Zhang Y, Huang B and Li X: Sevoflurane inhibits the migration and invasion of glioma cells by upregulating microRNA-637. Int J Mol Med 38: 1857-1863, 2016. PMID: 27840895. DOI: $10.3892 / \mathrm{ijmm} .2016 .2797$

28 Wang Q, Li K and Yao S: Effect of inhalational anesthetics on cytotoxicity and intracellular calcium differently in rat pheochromocytoma cells (PC12). J Huazhong Univ Sci Technolog Med Sci 28: 104-109, 2008. PMID: 18278471. DOI: 10.1007/s11596-008-0127-4
Received September 2, 2019

Revised September 21, 2019

Accepted September 25, 2019 